\title{
Lacanyen Bakış Açısından Pervert Yapı Kavramı ve Terapötik Öneriler
}

\author{
Burcu Pınar Gökdemir-Bulut* \\ Orta Doğu Teknik Üniversitesi
}

\begin{abstract}
Özet
Perversiyon, literatürde genellikle "suç teşkil eden eyle mlerde" bulun ma biç iminde anlaşılan bir kavra md ır; fakat Lacan bu kavra mı, nevroz ve psiko za e k ola rak üçüncü bir klin ik yapı ola rak tanımla maktadır. Lacan tarafından öne sürülen üç klinik yapının anlaşılması ve birb irlerinden ayrıştı̆̆ı noktala rın e le alın ması öne mlidir, çünkü bu yapıla r be lirli se mptomlar te mel a lınarak yaln ızca betimley ici teşhisler sunmanın ötesinde, bir tedavi modeli de sağlama ktadırla r. Perversiyonda özne, anneden ayrışmasına ze min hazırlayan ikinci baba işlevinin (Babanın Adı) et kili ola ma ması nedeniyle, büyük Öteki konumundaki annenin zev kin in nesnesi olmaya "Hayır" diye me me ktedir. İkinc i baba işlevinin başarısızlığa uğra masının ba zı nedenleri; baba işlevini "mış gibi görün meye/görüntüye" indirgeyen anne söylemi, kuralların gere klerine göre değil kendi duygularına göre çocuklarına kura 1 koyan ebeveyn tutumu, ensest ve cinsel istisma ra uğra ma o lara k tart ışılmaktadır. Baba işlevinin başarısız o lmasının sonucunda, annede algılanan eksik "tanın ma ma ktadır" (d isavowal) çünkü eksik babanın adı tarafından simgeleştirilmed iği sürece çocuk iç in trav matiktir. Bu de mektir ki; tanıma ma me kanizması, pervert lerin zevki kısıt la ması gere ken baba işlevinin güçsüzlüğü ve eksiğin o lmayışı ile başa çıkma yöntemle ridir. Maka lede, pervert yapının ö zelliklerini örneklendirme $\mathrm{k}$ iç in bir va ka ele a lınacaktır. Buna ek ola rak, Lacanyen bakış açısı teme l alınara k pervert yapı iç in terapötik önerile rde bulunulacak ve aynı vaka ile yürütülen terapi seanslarından bazı örnekler verilecektir.
\end{abstract}

Anahtar sözcükler: perversiyon, zevk, baba işlevi 


\section{Lacanyen Bakış Açısına Göre Perversiyon Kavramı: Pervert Yapı}

Perversiyon genellikle pedofili veya travestik fetişizm gibi cinsellik açısından negatif atıfları olan, "suç teşkil eden eylemlerde" bulunmak biçiminde anlaşılan bir kavramdır ve bu bakış açısı psikoloji ve psikiyatride baskındır (Verhaeghe, 2008). Psikanalitik görüş ise erken dönem modernitenin söylemleri olan ahlak ve günah açısından yaklaşılan perversiyona farklı bir bakış açısı getirmiştir (Penney, 2012). Freud, perversiyonu farklı bakış açısıyla kavramsallaştıran psikanalitik teorinin en önemli temsilc ilerinden birisidir. Freud, perversiyonu ilk olarak belirli kısmi bir dürtüye saplanıp, üremeye yönelik cinsel ilişkinin (adult genital relationship) imkânsızlaştı̆̆ gelişimsel bir bozukluk olarak tanımlamış ancak sonrasında bu tanıma uygun cinsellikler bulmanın oldukça zor olduğunu ve patolojik olanı sağlıklı olandan ayırt etmenin zorluğunu fark etmiştir. Bu noktada da bu görüşünü terk ederek, devreye savunma mekanizması kavramını dâhil etmiş, insanların cinsel gelişimlerinin patolojisini hem Oedipus kompleksi ile hem de kastrasyon kaygisı ile hangi savunma mekanizmalarını kul anarak baş ettiklerine göre açıklamıştır (Verhaeghe, 2001). Freud'a göre Oedipus kompleksinin merkezinde olan kıskançlık duygusudur ve bu duygu cinsellikten zevk alan ötekinden sürgün edilmenin acısı ile ilişkilidir. Çocuğun düşüncesinde, yetişkinler karşılıklı olarak yoğun, mutlu bir deneyim yaşamakta ve kendisi bu deneyimden tamamen dışlanmaktadır. Çocuğun "Ben sevgili ötekimin arzusunun ya da zevkinin nesnesi değilim.” düşüncesi kendisine acı vermektedir. Bu nedenle, ilk sahne aynı zamanda da ilk dışarda bırakılma sahnesidir. Nevrotikler travmayı aşma ve başkalarının hayatlarına dâhil olma istemlerine rağmen sürgün edilmişliklerine takılmışlarken, pervertler bu noktada kıskançlığın travmasını cinsel zevke dönüştürmekte ve sürgün edilmenin acısı ile bu şekilde baş etmektedirler (Benvenuto, 2006). Freud'a göre nevrotiklerin kastrasyon kaygılarından farklı olarak pervertler kastrasyon kaygısıyla baş edebilmek için tanımama (disavowal) mekanizmasını kul anırlar ve buna göre bir yandan annenin kastre edilmiş olduğunu kabul ederlerken bir yandan da bu durumu inkâr ederek annenin de penisi olduğuna inanırlar (Verhaeghe, 2001). Freud'un vurguyu gerçek penise ve gerçeğe yapması ise kastrasyon kaygısını ikna edicilikten uzaklaştırmış, pervert yapıları pervert özel iklerden ayırmayı mümkün k1lmamıştır(Verhaeghe, 2001). Lacan ise pervert yapı ile pervert eylemler arasında bir ayrıma gitmiş, Freud'un ileri sürdüğü kastrasyonun inkârı bağlantısını tutarak, perversiyonun anlamlandırılması için özdeşleşme kavramını da tabloya eklemiştir. Lacan'a göre pervert özne baba ile özdeşleşmek yerine, anne ve/veya Ötekinin imgesel fal usu ile özdeşleşmiştir (Verhaeghe, 2001; Evans, 1996). Bu makalede, Lacan'ın kavramsallaştırdığı şekildeki pervert yapının özel ikleri ve etiyolojisi, nevrotik yapıdan farklılıkları ve bu yapıya özgü terapi süreci açıklanacak ve bir vaka örneği bu boyutlar bakımından incelenecektir.

Lacan tarafından açıklanan üç klinik yapı nevroz (histeri ve obsesyonel nevroz olarak ikiye bölünür), perversiyon ve psikozdur. Her bir yapı öznenin (büyük) Öteki -sembolik düzene işaret etmektedir ve çoğu zaman da ebeveynler, eğitimciler ve otorite pozisyonundaki insanlar kastedilmektedir- ve eksikle -bir şeyin değil varlığın eksikliği, hiçbir zaman tamamlanmışlığı deneyimleyememek- ilişkisindeki farklı konumuna işaret etmektedir (Feher-Gurewich, 2003). Şöyle ki her bir pozisyonun Ötekinin özneden ne istediğini anlamak için kendisine ait bir yöntemi vardır. Obsesyonel nevrotik Öteki ile ona olan bağımlılığını reddederek, histerik Ötekini suçlayarak, psikotik bir şeyleri yönlendiren Ötekinin Ötekisinin olduğuna dair paranoid bir fikre sahip olarak Öteki ile ilişki kurarlarken; pervert Ötekinin "zevk" aracı olarak onunla ilişki kurar (Fink, 1997). Zevk kelimesinin Lacanyen kuramdaki Fransızca karşılığı olan "jouissance” İngilizce'ye "enjoyment” olarak çevrilmektedir fakat enjoyment kelime olarak jouissance kelimesinin cinsel imasını yansitamamaktadır (Evans, 1996). Ayrıca, jouissance saf zevkten daha fazlası olarak, acı ve zevkin birleşimidir (Swales, 2012).

Lacan'a göre her bir klinik yapı ayrıca kendi savunma mekanizmasına da sahiptir; bastırma (repression) nevrozdaki, tanımama (disavowal) perversiyondaki, hesaptan düşürme (foreclosure) psikozdaki 
savunma mekanizmalarıdır (Swales, 2012). Aslında her bir mekanizma ilişkili olduğu klinik yapının bir özel iği olmasının ötesinde o yapının temelinde yatan şeydir ve bu mekanizmalar Lacanyen bakış açısına göre ikincil düzeyde gelişen egonun savunma mekanizmalarından farklıdır (Rusansky Drob, 2008).

Bastırma mekanizması yoluyla, kişinin kendi görüşüyle uyuşmayan düşüncelerinin, ahlaki prensiplerin veya ilkel bastırma (primal repression) ile ilgili olan materyallerin bilinçdışından bilince çıkmasına izin verilmemektedir (Fink, 1997). Tanımama mekanizmasında, semptomlar bir şeyin algısının kişinin hafizasına kaydedildiğine ve depolandığına işaret etmesine rağmen; o algı ile ilgili düşünceler kişinin zihninden uzaklaştırılmış gibi görünmektedir (Swales, 2012). Hesaptan düşürme mekanizması, belirli bir unsurun sembolik düzene kaydedilmesini engel eyecek biçimde tamamen reddedilmesi anlamına gelmektedir ve bu belirli bir unsur esasen "baba işlevi” ile çocuğun kastre edilme tehdididir (Fink, 1997). Bu farklı mekanizmalar yabancılaşma (alienation) ve temel bakım veren kişiden ayrışma (separation) problemleri ile farklı baş etme yöntemleridir (Swales, 2012).

Pervert yapıda, özne Öteki olarak annenin zevkine "Hayır" diyememekte ve ona hizmet etmeye devam etmektedir. Buna göre; pervert kendi hazzı için değil, yalnızca Ötekinin zevki için harekete geçmekte; hazzı da kendini Ötekinin zevki uğruna araç haline getirmekten almaktadır (Taheri, 2016). Pervert, annenin fazla zevkinin aracı rolünü baba işlevi ile sınırlandırılmadı ğı için sürdürmektedir (Bernstein, 2015). Baba işlevinin görev yaptığı iki yer vardır. İlk baba işlevinin ortaya çıkması ki bu işlev anne ile hoşa giden temastan duyulan zevke babanın "Hayır" demesi -kısaca babanın "Hayır"1- şeklindedir ve Lacan'ın yabancılaşma kavramına denk gelmektedir (Fink, 1997). Yabancılaşma, bireyin -var oluşununortadan kaybolmasını içermektedir (Fink, 1995); yani sembolik düzende bir özne olabilmek için biraz zevk feda etmektir (Bernstein, 2015). İkinci baba işlevi ise "Babanın Adı" olarak bilinmektedir ve annenin eksikliğinin isimlendirmesi yoluyla Öteki konumundaki annenin zevk kaynağı olmaktan ayrışmaya işaret eder; böylece eksik sembolize edilmiş-simgeleştirilmiş olur (Swales, 2012). Çocuk annenin kendisinden başka arzuladığı başka şeylerin de olduğunu (baba, kariyer gibi) ve annenin hayatındaki tek doyum kaynağı olmadığını anlar. Bu yolla da çocuğa kendi arzularını üretmesi için sembolik boşluk açılmış olur (Swales, 2010); eksiğin sembolize edilmesi arzulayan bir özneyi ortaya çıkartır. Pervertler için olan durum ise yabancılaşma gerçekleşirken ayrışmanın olmamasıdır (Swales, 2012) ve bunun sonucu eksiğin sembolize edilememesidir. Annenin fal usa sahip olmadığını (göstereni olmayışına işaret eder) ve dolayısıyla onun eksik olduğunu algılayan çocuk, bu travmatik algıyı kabul etmez çünkü baba işlevi tarafindan eksik simgeleştirilmemiştir (Fink, 1997). Lacan'ın 1962-1963 yıllarında kaygı üzerine verdiği 10. Seminerinde belirttiği gibi “Eksik ancak simgeselin arabuluculuğu vasıtasıyla kavranabilir.” (s. 132). Sonuç olarak da, perversiyonda eksikliğe dair kavrayış "tanınmamaktadır".

İkinci baba işlevinin sekteye uğramasından ötürü, baba yalnızca "Babanın Adı" olarak sembolik şeklide tanınmakta ve bu tanınmanın dışında baba gerçekte reddedilmektedir. Bu durumda, baba bir taraftan aile içerisinde tanınırken, diğer taraftan da babanın yasayı ve otoriteyi temsil eden sembolik baba konumu tanınmamaktadır. Babanın bu çelişkili konumu çoğu zaman gerçek babanın bir başınalığından veya görevinden feragat etmesinden çok, annenin babanın yeri hakkındaki söylemi ile ilgilidir ancak bu ifade gerçek babanın çocuk üzerinde hiçbir etkisinin olmadığı anlamını içermemektedir. Anne sembolik babayı yüzeysel bir biçimde tanımakta ve de babanın korunması ve saygı duyulması gereken otoritesini "-mış gibi görünme/görüntüye" indirgemektedir. Babanın otoritesi "yalnızca" sembolik bir değere indirgendiğinde; bir sembol olmanın resmiyetini kaybeder ve uyulmadığında herhangi bir yaptırımı olmayan bir yasa olarak nitelendirilir. Pervertin dünyası bu bakımdan iki sahneden oluşmaktadır: ilki, topluma ve babanın kural arının, otoritenin ve yasaların bel i olduğu görünüme işaret eden umumi sahne; ikincisi ise anne ve çocuğun dışardaki dünyanın yasalarından kendilerini azat ettikleri özel sahnedir (Andre, 2006).

Sosyal düzenin ötesindeki maskeyi, yani “mış gibi görünenleri/görüntüleri” keşfetmek pervertlerin amacıdır ve bu yolla Öteki konumundaki anneden onun zevk nesnesi olarak ayrışamamış olmanın ve eksiği 
kavrayamamanın kaygısını dindirebilmektedirler (Feher-Gurewich, 2003). Lacan'ın (1962) belirttiği gibi; çocuğa en çok ızdırap veren an, eksikle kurduğu ilişkinin arzuya dönüşmesi aksadığında yaşadığı andır. Eksikle kurulan ilişki en çok, eksik imkânsız olduğu zaman, anne her zaman kişinin sırtında durduğunda aksar (s. 53). Bu nedenle aslında perversiyon baba işlevinin zevki kısıtlayacak gücünün eksikliği ile baş etme stratejisidir ve pervertin baş etme yöntemi de "tanımamadır" (Swales, 2012); tanımama, yasanın algılanması ancak yasayı bilmeye direnmedir (Bernstein, 2015). Bu yüzdendir ki pervertlerin "zevk istemleriwill to jouissance" yasayı var etme amaçlarını gizleyen bir maskedir ve bu maskeden ötürü çoğu zaman terapistlerin de dâhil olduğu nevrotikler, yanlış bir biçimde pervertlerin doğrudan cinsel doyuma ulaşmaya yönelik eylemlerde bulunduklarına inanırlar (Fink, 1997).

Baba işlevini “mış gibi görünmeye/görüntüye” indirgeyen anne söylemine ek olarak, yalnızca çocuklarına sinirlendikleri zaman onlara kural koyan ebeveynlerin tutumu da kural koyucu Öteki ile ilişkiyi olumsuz anlamda etkilediği tartışılan diğer bir etmendir. Aslında çocuğun yasayı içsel eştirebilmesi ve yasanın keyfi bir şey olmadığını anlayabilmesi için ebeveynin çocuğun davranışlarını kendi isteklerine göre değil, yasanın gerekliliklerine göre sınırlandırması gerekmektedir (Swales, 2012). Baba işlevinin olumsuz etkilenmesine sebebiyet veren diğer etmenler ise ensest ve cinsel istismar olarak görülmektedir. Ensest ve cinsel istismar durumlarında, Ötekinin bildiği varsayılan ve güvenilir özne konumu Öteki ile olumlu anlamda işleyecek bir ilişkinin kurulmasını önleyecek biçimde zarar görür. Bu da en nihayetinde Oedipal yasanın başarısızlığına katkıda bulunur (Verhaeghe, 2001).

\section{Pervert Yapının Nevrotik Yapıdan Ayrıştırılması}

Lacan tarafından öne sürülen 3 klinik yapının birbirinden ayrıştırılması önemlidir çünkü bu ayırımı yapmak, belirli semptomlar temel alınarak yalnızca betimleyici teşhisler sunmanın ötesinde bir tedavi modeli de sağlamaktadır (Swales, 2012). Diğer bir taraftan ise bireyin, dâhil olduğu yapıdan ziyade başka bir yapının niteliğini taşıyan davranışlar sergileyebilmesi nedeniyle, bu yapıları birbirlerinden ayırmak bir miktar karmaşık bir konudur. Buna göre, bir yapıda olmak diğer bir yapının davranışlarını sergileme olasılığını tamamen dışarda bırakmamaktadır (bu açıklama da yine yapı ve davranış arasındaki farkı vurgulamaktadır) (Evans, 1996). Yine de yapılar arasındaki ayrımı yapmanın zorluğu, bu ayrımı yapmayı imkânsız kılmamaktadır. Bu makale kapsamında perversiyonun yalnızca nevrozdan (ki burada nevrozdan kastedilen temel anlamda histeridir) farkı ele alınacaktır. Perversiyon ve psikoz arasındaki farktan ziyade perversiyon ve nevroz arasındaki farka odaklanılacak olmasının nedeni, hem pervertlerin hem de nevrotiklerin sembolik düzene girmiş olmaları; psikotiklerin ise tamamen imgeselde yaşamalarıdır (Rusansky Drob, 2008). Dahas1 nevroz sıklıkla perversiyonun negatifi olarak tartışılmaktadır (Richards, 2003); bu da onların aslında benzer bir temelden geldiklerine işaret etmektedir. Nevroz ve psikoz ile ilgili olarak Lacan 1958 yılında bilinçdış1 ile ilgili verdiği beşinci seminerinde şöyle demiştir: “... Sonuç olarak eğer bir fark varsa; bu fark sınırlarının çizilmesini fazlasıyla hak etmektedir"' (s. 208).

Arzuyu onun gerçeğe dönüşmesinden kaçarak canlı tutan nevrotiklerden farklı olarak pervertler, kendilerini bu süreçte kurban etmeleri pahasına sonuna kadar yaşamaktadırlar (Feher-Gurewich, 2003). Lacan (1973) bu durumu, "Nevrotikler, pervert eylemlere değil; bu eylemlerin hayal erine bağlıdırlar. Yani nevrotikler, pervertlerin özel iklerine sahip değildirler ve basit bir şekilde pervert olmanın hayalini kurarlar ki bu da oldukça doğaldır, öteki türlü eşlerine erişmeleri nasıl mümkün olabilir?” diyerek açılamıştır (s. 87). Dolayısıyla, perverti nevrotikten ayıran önemli nokta; fantezilerinin içeriğinden ziyade fanteziye ilişkin özne olarak aldığı konumudur. Nevrotik yapıdakiler fantezilerini konuşmaya dökmezlerken, pervertler fantezilerini açık açık dile getirmeleriyle birlikte, eğer Ötekini yalnızca pervert davranışlarla ikna edemediklerini hissederlerse, hem fantezileri üzerinde hak iddia ederler hem de Ötekini kendi fantezilerini dinlemeye zorlarlar (Andre, 2006). Bu davranışlarının amacının Ötekinin dikkatini çekmek 
olduğu söylenebilir (Swales, 2012). Bu durumun pervert hastaların akıllarına ne gelirse söylemekte tereddüt etmemelerinin ve söylediklerine ilişkin neredeyse hiç utanç veya endişe duymamalarının nedeni olabileceği düşünülmektedir.

Ötekinin zevk nesnesine indirgenmek en dehşet verici şey olduğundan dolayı nevrotikler, bu duruma düşmekten kaçma amacı güderler ancak pervertler, nevrotiklerin kaçtığı durumu gerçeğe dönüştürürler (Verhaeghe, 2008). Pervertlerin nevrotiklerde korku ve endişe duyguları uyandırmalarının nedeni de Ötekinin fantezisinin uygulayıcısı olmalarıdır ki bu da onların psikolojik doyuma ulaşmalarının tek yoludur (FeherGurewich, 2003).

Makalenin aşağıdaki bölümünde, örnek bir vaka özetlenecek ve sonrasında bu vaka Lacanyen anlamdaki pervert yapı göz önünde bulundurularak tartışılacaktır. Bunlara ek olarak pervert yapı için ortaya konulan pratiğe yönelik öneriler detaylandırılacak ve özetlenen vaka ile yürütülen terapi seanslarından örneklerle (yalnızca bu önerilere uyan değil bu önerilerin aksinin uygulandığı örnekler de dahil edilerek) açıklanacaktır.

\section{Pervert Yapı Açısından Vaka Örneği: M. Hanım}

M. Hanım 26 yaşında, bekâr bir kadındır. M. Hanım'ı terapiye yönlendiren kişinin kendisine bipolar bozukluk teşhisi koyan ve ilaç tedavisine ek olarak terapiyi öneren bir psikiyatrist olduğu öğrenilmiştir. Bu yönlendirme sonucunda M. Hanım'ın Ayna Kliniği'nden 6 yıl önce terapi hizmeti almaya başladığı ve önceki iki terapistinin de eğitim süreçlerini tamamlamaları nedeniyle klinikten ayrlarak kendisini transfer ettikleri bilgileri edinilmiştir. Bizim seanslarımız ise 3 yıldır devam etmektedir. Kendisi ile yürütülen terapi süreci her ne kadar eklektik yaklaşıma göre (M. Hanım'ın sınırdurum kişilik özel ikleri gösterdiği düşünülerek) şekil endirilmiş olsa da, bu makalede vaka, Lacan'ın perversiyon kavramı temel alınarak formüle edilecektir.

Birlikte yürüttügümüz ilk seansta, M. Hanım terapiye devam etmek istemesinin nedenlerini yalnızlıkla başa çıkamaması ve boşluk hisleri olarak belirtmiştir. Kendisinin yine tıpkı lisede olduğu gibi davranmaya başladığını, yani kimseye güvenemediğini ve insanlarla iletişim kurmak enerji gerektirdiği ve bu enerjiyi harcamak istemediği için de ilişki kurmakta güçlük yaşadığını ifade etmiştir. M. Hanım zaman zaman da kendisini değersiz hissettiğinden söz etmiştir. M. Hanım'ın şikâyet olarak dile getirdiği boşluk hisleri, insanlarla ilişki kurmak için gönülsüz olması ve kırılgan kendilik değeri, Ötekinin zevkinin aracı olmakla ilgili yaşadığı problemlerin işaretleri olarak yorumlanabilmektedir. Daha açık bir şekilde ifade etmek gerekirse, zevk feda edilmediği sürece eksik kabul edilmemekte; eksiğin kabul edilmediği durumda da arzulayan nesne ortaya çıkamamaktadır. Arzu olmayınca özne etrafındaki şeylere, nesnelere ve varlıklara karşı oldukça az miktarda ilgi duymaktadır (Ruti, 2008).

M. Hanım özel ikle ilk seanslarda, ailesini çok da umursamadığını düşündüğü için onlarla ilgili konuşmak istememiştir. Anne ve babası hakkında bilgi toplamaya çalışıldığında babasına kıyaslandığında annesini çoğunlukla çok daha olumsuz bir şekilde tarif etmiş ve ona hiçbir zaman ihtiyaç duymadığını vurgulamıştır. Annesiyle ilgili ilk tanımlamaları cahil, salak, vasıfsız, konuşacak bir konusu olmayan, korkak, çekingen, kimseyle doğru düzgün ilişki kuramayan, pis ve yavaş hareket eden bir kadın olmuştur. Ancak seanslar ilerledikçe M. Hanım, annesinin olumlu olarak gördüğü birkaç özel iğinden söz etmeye ve aslında daha iyi ilişki kurabildiği bir anne figürüne ihtiyaç duyduğunu söylemeye başlayabilmiştir. İlk seanslarda babasının çok çalışkan, atik, hızlı kararlar alabilen, zeki birisi olduğuna daha çok vurgu yapan M. Hanım, sonralarda babasının çok sinirli olduğunu, her şeyde kendisini suçlu bulduğunu ve ancak "büyük bir sorun" çıkarttı̆ğında kendisine sert bir yolla müdahale eden birisi olduğunu dile getirmiştir. M. Hanım, kardeşleriyle ilgili olarak (evin en büyük çocuğu kendisidir ve kendisinden 1.5 yaş küçük bir kız kardeşi 12 yaş küçük de bir erkek kardeşi vardır) kız kardeşiyle arasının iyi olduğu fakat erkek kardeşiyle 
pek anlaşamadığı, zaten ergenlik dönemindeyken anne ve babasına sinirlendiğinde erkek kardeşine şiddet uyguladığı bilgilerini vermiştir. M. Hanım, erkek kardeşinin aslında doğmaması gereken bir çocuk olduğunu düşündüğünü çünkü ailesinin çocuk yetiştirme konusunda yetersiz olduklarını belirtmiş, annesi hamile olduğunu söylediğinde "Siz ne ara yattınız?" şeklinde bir tepki verdiğini de dile getirmiştir. Annesi ve babasını çocuk yetiştirmek konusunda yetersiz bulduğunu sıklıkla vurgulamasına rağmen bu düşüncesinin altında yatan nedenler sorgulandığında, genellikle konuyu değiştirme eğiliminde olmuş ve huzursuz bir izlenim vermiştir. İlerleyen zamanlarda, ailesinin çocuk yetiştirme stilinin ya hiç kural koymayan ya da her türlü olumsuzluktan kendisini suçlu bulan ve onu cezalandıran bir tarzda olduğunu açıklamıştır. M. Hanım uyulması gereken kural arı (çoğu zaman toplumdaki kural ara işaret ederek) oldukça saçma bulduğunu ve yasak olana yönelmenin kendisi için heyecan verici olduğunu paylaşmıştır. İlk bakışta M. Hanım'ın kural ara ve yasaklara bu açıdan yaklaşması ailesiyle ilgili şikâyetleriyle tutarsız gibi görünmektedir fakat kural ar ile ilgili rahatsızlığı detaylı olarak incelendiğinde, M. Hanım'ın kural arı bireyler arası farklılıkları tamamıyla yok edecek biçimde, çok katı algıladığı fark edilmiştir.

Pervertlerin temel problemi de yasa ile özdeşlik kurmada güçlük çekmeleridir (Rusansky Drob, 2008). Bu problemlerinin nedeni Fink' in (1997) ifade ettiği gibi ne annenin ne de babanın simgeleştirme için gerekli eklemlenmeyi sağlayamamış olması, yani yasa koyucu Ötekinin yetersiz olmasıdır. Bunun sonucu olarak da pervert, Oedipal-öncesi dönem zevkinden duyduğu keyfi terk etmeyi reddetmektedir (Swales, 2012). M. Hanım ailesinin kendisine hiç bir kural koymadığını ve hatta onların kendisini korumamalarından dolayı bekâretini kaybettiğini -ki bekâret konusunda kızlık zarının adil bir oluşum olmadığını ve kadınlara gereksiz bir yük getirdiğini düşündügünü, ilk cinsel birlikteliğini de ondan kurtulmaya çalıştığı için deneyimlediğini ifade etmesine rağmen- söylemiştir. M. Hanım babasına yalanlar söylediğini ancak babasının bu yalanları ortaya çıkaran ipuçlarına dikkat etmediğini dile getirmiştir. Örneğin, arkadaşlarıyla birlikte güzel zaman geçirmek için dışarı çıktığında ailesine dershaneye gittiğini söylediğini, sonrasında da kendisini eve götürmesi için babasını dershanenin önüne çağırdığını anlatmıştır. Babasının dershanenin 1şıklarının kapalı olduğunu fark etmediğini ve bir dershanenin o kadar geç saate kadar nasıl açık olduğunu sorgulamadığını belirtmiştir. Diğer taraftan ise babasının kendisinin serseri gibi dışarlarda arkadaşlarıyla geziyor olmasına sinirlendiğinden ve hatta sinirlendiğinde kendisine zaman zaman "orospu" dediğinden söz etmiştir. Küçüklügünde ise annesinin yaramazlık yaptığını söyleyerek kendisini babasına şikâyet ettiği zamanlarda, babasının kendisine vurduğunu aktarmıştır. M. Hanım babasını bir yandan -yasa ile özdeşleşmeyi engel eyecek kadar- agresif olarak, diğer yandan da söylediği yalanlara işaret eden ipuçlarının farkında bile olamayacak kadar ilgisiz olarak tanımlamıştır. Babanın bu biçimde tutarsız algılanması, babanın otoritesinin yalnızca sembolik değere indirgemesinin nedeni olabilir. Benzer bir şekilde, M. Hanım, annesinin dışarıda erkeklerle takıldığının farkında olduğunu ancak ne yaptığını sorgulamadığını belirtmiş, annesinin de kural koymadığını "Annem derslerine çalış demek dışında hiç kural koymadı.” diyerek ifade etmiştir.

M. Hanım'ın yasa ile özdeşleşmesindeki zorluk (kural ara uymakta güçlük şeklinde kendisini bel i eder) ve kural arın tutarsızlığına karşı hassasiyeti terapi sürecinde de kendisini göstermiştir. Özel ikle ilk zamanlarda geç kaldığı ve hatta haber vermeden gelmediği seanslar olmuştur. M. Hanım ile 15 dakikadan daha fazla geç kaldığı bir seansta geç kalmalarının seansları olumsuz yönde nasıl etkilediği konuşulduktan sonra, terapist tam zamanlı bir seans yapmak yerine seansı bitirmişt ir. Bu konuşmadan sonra M. Hanım seanslara zamanında gelmeye başlamış ancak bu sefer de seans ücreti ödemelerini geciktirme sürecine girmiştir. Bu konu terapist tarafından açıldığında M. Hanım, terapiye ilk başladığında seansların ücretsiz olduğunu, bu yüzden de hem terapi hizmeti alanların hem de terapistin (kendisi gibi kampüsteki öğrenciler için ücretsiz terapi hizmeti; terapistler için eğitim anlamında fayda) yürütülen bu süreçten faydalandığını düşündüğünü söylemiştir. M. Hanım, Ayna Kliniği'nin ücret politikasındaki tutarsızlığa sinirli bir şekilde tepki vermiş; hasta sayısı arttı̆̆ için Ayna'nın ücret politikasını değiştirdiğini ve bunu samimiyetsiz 
bulduğunu ifade etmiştir. M. Hanım'ın bu kadar sinirlenmesinin nedeninin ailesinde tabii tutulduğu yasaların yanılsamalarını algıladığı zamanlarla benzerlik kurarak, Ayna'nın da "açı̆̆ını yakaladığını" düşünmesi olduğunu söylemek mümkündür.

Makalenin ilk kısmında, babanın yasasının başarısızlığının arkasındaki bir diğer nedenin de güvenilir Öteki pozisyonundaki birisi tarafindan cinsel istismara uğramak olduğu tartışılmıştır. M. Hanım, 50'li bir yaşta olduğunu tahmin ettiği, öğretmenlik yapan ve ailecek görüştükleri bir komşuları tarafindan ilkokul dönemindeyken tacize uğradığını anlatmıştır. M. Hanım, ailesinin kendisini o kişinin hafta sonları verdiği kursa gitmeye zorladığını, derslerde o kişinin kendisini birkaç kez kucağına oturttuğunu ve bu durumdan ne olup bittiğini anlamadığı halde rahatsızlık duyduğunu dile getirmiştir. Bu tanımlayamadığı rahatsızlık hissinden dolayı kurstan ayrılmak istediğini, ancak anne ve babasının bu ayrılma isteğini derslerden kaçış olarak yorumlamaları nedeniyle ilk başta buna hemen izin vermediklerini belirtmiştir. M. Hanım, üniversitede cinsel istismar ile ilgili bir makale okuyana kadar cinsel istismara uğradığının farkına varamadığını da eklemiştir. Buna ek olarak M. Hanım, kendisinden 7-8 yaş büyük olan ergenlik dönemindeki bir erkek komşuları tarafından da taciz edildiğini, "Vücutta bir şeyler saklama oyunu oynardık ve yalnızca ben eşyayı kolay bir yere koyardım” diyerek aktarmıştır. Her iki taciz olayında da kişiler güvenilir olmaları beklenen komşulardır.

Terapi sürecinin başında M. Hanım, A. Bey ile yaklaşı 5 yıldır süren bir ilişkisinin olduğunu (ilişkileri yaklaşık 2 yıl önce sona erdi) ve bu ilişkinin içerisinde hem kendisinin partnerini aldattığını hem de onun tarafindan aldatıldığını söylemiştir. M. Hanım bu ilişki ile ilgili olarak ayrıca şiddete maruz kaldığını, birçok kez ondan ayrılmaya kalkıştığını ancak her ayrılıktan sonra kendisini çok kötü hissederek bu "hastalıklı ilişkiye" geri döndüğünü anlatmıştır. M. Hanım ancak A. Bey üniversiteyi bırakıp başka bir şehre gittiğinde ondan ayrılabildiğini de eklemiştir. M. Hanım’ın A. Bey’den ayrılması ile ilgili yaşadığı bu süreç de Lacanyen bakış açısına göre yorumlanabilir. M. Hanım, A. Bey'in kendisini pasif bir rolde tutması, zaman zaman şiddet uygulaması, aldatması ve başka erkeklerle görüşmesi konusunda kısıtlaması nedenleriyle ondan ayrılmayı uzun bir süre boyunca denediğini ancak her seferinde bir şekilde ona geri döndüğünü söylemiştir. M. Hanım, ayrılma sürecinin zorluğundan ziyade A. Bey'den ayrılamıyor olmaktan şikâyet etmiş, hatta bir seansta kendisi ve A. Bey arasındaki durumun Stockholm Sendromuna uyduğunu söylemiştir. Bu durum, Lacan'ın ayrılık kaygısının "babanın adı" vasıtasıyla (anneden) ayrışmanın başarısızlığa uğramasından kaynaklandığı fikri ile tutarlı görünmektedir. Ayrıca M. Hanım'ın kendisine bu denli zarar veren bir ilişkiyi sürdürmesi, bir diğer taraftan da pervertin (spesifik olarak mazoşistik perversiyonda) bağırıp çağıran baba ve annenin, aslında öfkelenerek, kendisini utanç hissetmekten ve acı çekmekten kurtardığını kabul etmesiyle de ilişkilidir (Fink, 1997). M. Hanım'ın A. Bey'i babasına benzetmesi, her ne kadar hoşlanmasa da kendisine koyulan sınırlardan sıkça bahsetmesi de bu bakış açısından tutarlı görünmektedir.

M. Hanım'ın A. Bey'den ayrılır ayrılmaz, A. Bey'in yakın arkadaşı olan ve A. Bey ile ilişkisi sürerken cinsel birliktelikler yaşadığı kişi ile romantik bir birlikteliğe başladığı bilgisi edinilmiştir. M. Hanım yeni ilişkilerle ilgili olarak başlangıçlardan hoşlandığını fakat zaman geçtikçe ilgisini kaybettiğini ve yeni bir başlangıç istediğini ifade etmiştir. M. Hanım, bu defa ilişkisindeki kişiyi aldatmayacağına yönelik kendisine bir söz vermesine rağmen, bir süre sonra başka bir erkeğe âşık olmuş ve bir yandan ilişkisini sürdürürken bir yandan da âşık olduğu kişi ile görüşmeye başladığını anlatmıştır. Bu kişinin eski kız arkadaşı ile barıştığını ve kendisine bu konuda yalan söylediğini fark edinceye kadar da onunla görüşmeye devam etmiştir. M. Hanım bir erkekle düzenli bir ilişkiyi sürdürmek isterken, aynı zamanda o kişinin kendisine başka erkeklerle de beraber olması konusunda izin vermesini istediğini dile getirmiştir. Birlikte olduğu erkeğin başka kadınlarla birlikte olmasına izin vermek konusunda ise kafasının karışık olduğunu söyleyen M. Hanım, bir yandan sevgilisini kıskanabileceğini bir yandan da birbirlerine karşı hislerinde bir değişim olmadığı sürece sevgilisini arzulayan başka kadınların olmasının kendisinin o ilişkiye 
olan düşkünlüğünü artıracağını düşündüğünü paylaşmıştır. M. Hanım'ın çoğunlukla kısa sürede romantik anlamdaki ilişkilerinden sıkılması ve yeni kişilerle görüşme isteğinin artması, pervertlerin nevrotiklerdeki gibi arzunun nesnesi olmaları yerine, zevkin nesnesi olmalanı ile dolayısıyla da genellikle kısa süreli ilişkiler kurma eğiliminde olmalarıyla ilişkilendirilebilir. Pervert, Ötekinin zevkini yeniden canlandırmaya çalışır çünkü Ötekindeki eksiği sıfira indirmek onun esas fantezisidir. Oysa bunu yapmak Öteki her zaman eksik olduğu için yapısal olarak imkânsızdır (Swales, 2012).

M. Hanım, insanlarla ve özel ikle de erkeklerle ilişkilerine yönelik olarak onları eğlendirdiğinde kendisini mutlu hissettiğini ve aralarındaki iletişimin bu şekilde kuvvetlendiğini belirtmiştir. Aslında $\mathrm{M}$. Hanım iletişim kurma aracı olarak insanlara sık sık "salak, kolay ve komik bir kız" izlenimi verdiğinden söz etmiştir. Dahası M. Hanım bir cinsel birliktelik sırasında erkeğin yüzüne baktığını ve eğer o zevk alıyorsa ona göre kendisinin de zevk aldığını vurgulamıştır. Cinsel birliktelik esnasında karşı tarafın hislerine odaklanması günlüğündeki ifadelerine de yansımıştır. Örneğin, günlüğüne “... Doğru mimikler, doğru sesler, doğru dokunuşlar ve öpüşler durumu karşı taraf için mükemmelleştirmeye yetiyor.” yazmıştır. Hem sosyal etkileşimlerindeki hem de cinsel ilişkilerindeki konumu Ötekinin zevkinin nesne rolü olması çerçevesinde değerlendirilebilmektedir. M. Hanım'ın günlüğündeki bir diğer cümlesi "İğreniyorum, nefret ediyorum ama bir yandan da bu yapay sevginin, ilginin getirdiklerinden vazgeçemiyorum.” şeklindedir ve bu cümle zevk nesnesi olması hakkındaki ikilemini göstermektedir çünkü M. Hanım bu konumdayken hem acı çekmekte hem de zevk duymaktadır. Bu da nevrotiklerin imtina ettikleri o konumdan, M. Hanım'ın "jouissance" çıkarttı̆̆ anlamına gelmektedir.

Pervertin jouissance ile kurduğu özel ilişkinin arkasındaki amaç, babanın yasasını desteklemektir. M. Hanım için bu amaç, onun insanlardan beklentilerinden anlaşılabilmektedir. M. Hanım kendisiyle etkileşime giren her kişinin zeki olmasının çok iyi olabileceğini çünkü zeki birisinin yanında durmanın sanki yanında seyyar bir öğretmen taşımak gibi olduğunu söylemiştir. M. Hanım, öğretmenin tanımını kişinin ufkunu açan, hayatı öğreten ve bir sıkıntısı olduğunda onu paylaşabileceği kişi olarak tanımlamıştır ki bu tanımlama babanın yasasının uygulayıcısı olarak saygı duyabileceği bir figüre ihtiyaç duymasıyla yakından ilişkili gibi görünmektedir. Benzer şekilde üniversitedeki en favori hocasının kural arı net ve iyi tanımlanmış bir erkek olduğunu belirtmiştir.

M. Hanım ile ilgili önemli görülen bir diğer yön yazı yazmayı sevmesidir ve çok iyi tanınan bir yazar olma konusundaki umutsuzluğuna rağmen aslında kısa öykü veya roman yazarı olmak onun hedeflerinden bir tanesidir. Swales'in (2012) dikkat çektiği gibi yazmak, pervertlerin pervert senaryolarını davranışa dökmeden süblime etmeleri için kul andıkları bir yöntemdir dolayısıyla da terapi süreci içerisinde de önemli bir konuma sahiptir. Bu yüzden, M. Hanım, bir dönem bıraktı̆̆ı yazı yazmaya tekrar teşvik edilmiş, seanslara getirdiği ya da mail olarak yolladığı yazılar üzerinde konuşulmuş, kendisini tamamen olmasa da büyük oranda yansıttığını söylediği kısa öyküsü “Kırmızı” dikkatli bir şekilde incelenmiştir. Öyküsünde “...Görülmesin istedim güzelliğim. Görülmesin ki kadınlığımdan bir parçacık haz almak için yapılan mücadele bana zarar veremesin ama bundan nefret ettiğim kadar haz duydum, insanım işte Tanrıça dediğiniz ben insanım sadece." yazmıştır. Ayrıca karakteri Kırmızının ağzından "Güzel olursa konuşmasına fazla gerek kalmıyordu, (böylece) şu aptal iç sesinin en olmadık dakikalarda konuşmasını da güzelce engel emiş oluyordu. O (aptal iç) sese, çirkinliğe ve güçsüzlüğe tahammülü yoktu." şeklinde bir cümle de yazmıştır. Seanslarda da, güzellik konusu ile ilgili olarak M. Hanım, yaşlanacağından, hayatta en değerli varlı̆̆ olan güzelliğini de yaşlanarak kaybedeceğinden ve bir daha güzel olamayacağından korktuğunu sık sik dile getirmiştir. Hem yazdığı öyküdeki cümleleri hem de seanslardaki şikâyetleri göz önüne alındığında, M. Hanım'ın Öteki ile ilişki kurmasını sağlayan tek yol olduğunu düşündüğü güzelliğini kaybetmekten korktuğunu söylemek mümkündür. Çirkinlik ve güçsüzlük aynı zamanda eksiğin işaretleridir ve eksik pervertin dünyasında kabul edilemez bir şeydir. 


\section{Lacanyen Bakış Açısından Perversiyon için Terapötik Öneriler}

Daha önce de belirtildiği gibi, Lacanyen teoride klinik yapıya karar vermek terapi süreci için ipuçları barındırmaktadır. Bu yüzden bu bölümde, Lacanyen bakış açısına göre pervert hastalarla çalışma sürecindeki önemli noktalar belirtilecektir. Buna ek olarak her ne kadar bu bakış açısına göre ilerlenmemiş olsa da, $\mathrm{M}$. Hanım ile yürütülen terapi sürecinden bazı örnekler verilecektir.

Nevroz ve perversiyonun Ötekine ilişkin pozisyonlarındaki ortaklıklarından dolayı pervertler -her ne kadar süreç içerisinde farklı problemler ortaya çıksa da- nevrotiklerle, özel ikle histeriklerle, benzer bir şekilde ele alınabilirler (Evans, 1996). Bu da demektir ki serbest çağrışım, rüyaların, fantezilerin ve tekrarlamaların analizi, geçmiş hakkında konuşulması gibi klasik teknikler, hem nevrotikler hem de pervertler için uygundur (Swales, 2012).

Her ne kadar bazı durumlarda hastalar, pervert senaryolarını terapi sahnesinde işleterek terapisti pervert davranışlarını yasa koyucu Öteki olarak yasaklamak ile yasak koymayarak risk almak arasında bıraksalar da, psikanalitik yaklaşımın amacı bu davranışların ortadan kaldırılması değildir (Swales, 2012). Farklı partnerlerle korunmadan cinsel ilişkiye girme (bu ilişkiler, çoğu zaman çok kısa süreli ilişkilerdir ve M. Hanım bu birlikteliklerden sonra hamile kalmaktan korktuğunu söylemiştir), marketlerden bazı ürünler çalma gibi pervert davranışlar zaman zaman M. Hanım ile yapılan görüşmelerin konusu olmuştur. Özel ikle ilk seanslarda, terapist endişe duyduğu için M. Hanım'ın pervert davranışlarının sıklığını azaltma eğiliminde olduğunu fark etmiştir. Örneğin, ilk seanslardan birisinde, M. Hanım'ın korunmasız cinsel ilişkilerini durdurmak için "Kendinizi cinsel birleşmeler sırasında korumalısınız." diyerek erken bir girişimde bulunmuştur ve bu girişim başarısızlıkla sonuçlanmıştır. Aslında risk taşıyan durumlarda terapist ve hasta arasında güçlü bir terapötik iş birliği olduğu sürece gerekçesi ile birlikte bir kısıtlama getirilebileceği de ileri sürülmüştür (Swales, 2012). Terapistin erken girişiminin başarısızlıkla sonuçlanması, güçlü bir terapötik iş birliği kurulmadan gerçekleştirildiği için şaşırtıcı değildir. Neyse ki terapinin odağı, yasakları empoze etmekten M. Hanım'ın insanlarla ilişkili olarak nasıl bir konum aldığını anlamasına yardımcı olmaya doğru dönmüştür.

Pervertin Ötekinin zevk nesnesi konumunda olması, terapistini güldürmeye çalışması ya da terapistte kaygıya neden olması biçimlerinde terapiye yansımaktadır fakat terapistin karşı-aktarım tepkilerini yöneterek tarafsızlığı koruması önemlidir. Sadece bu şekilde pervertin "nesne a" konumundan vazgeçebileceği ileri sürülmektedir. Nevrotik terapist ise, zevk açısından kısıtlanmış hayatına kıyasla, pervertin zevk dolu bir hayat yaşadığı varsayımında bulunmaya meyillidir. Bu varsayım, hastayı dinlemekten alınan zevkin açığa vurulması riskini taşımaktadır (Swales, 2012). M. Hanım ile yürütülen terapi süreciyle ilgili olarak süpervizörlerden birisi terapistle hasta arasındaki karşılıklı gülüşmelere dikkat çekmiştir. Buna ek olarak terapist de, M. Hanım'ın konuşmaları yaşadığı olumsuz deneyimlerle ilgili olsa da bu içeriği eğlendirici bir biçimde ilettiğini ve kendisinin de buna kapıldığını hissetmiştir ve bu açıdan daha dikkatli davranmaya başlamıştır.

Terapi sürecinin ilk başındaki seanslarda, nevrotik hastalara kıyasla, pervert hastalar kendilerinin kim olduklarına ve neden böyle olduklarına dair daha az soru sorma eğiliminde olurlar. Bu yüzden de terapist hastanın kendisine olan merakını desteklemelidir. Eğer ki hasta "Neden bilmiyorum..." gibi bir cümle kurarsa terapist seansı bitirebilir ve böylelikle hasta kendi eksikliği ile yüzleşebilir (Swales, 2012). M. Hanım terapiye geldiğinde terapist, M. Hanım'ın kendisi de dahil olmak üzere her şeye karşı ilgisini yitirdiği, etrafinda ne olup bittiğine karşı kayıtsız olduğu izlenimini edinmiştir (çok fazla uyuyor ve nadiren dışarıya çıkıyordu). M. Hanım, geçmiş deneyimleriyle ilgili konularda ya da kendisi için önemli olabilecek konularda çoğu zaman “Bunu konuşmaya değmez.” demiş ve konuyu kapatmaya çalışmıştır. Bir yandan da seanslar ilerledikçe, bu örüntü önemli bir ölçüde değişmiş; M. Hanım kendi gündemlerini getirmeye başlamış ve üzerinde konuşmak istediği alanları belirlemiştir. Örneğin, seansların son yılında M. Hanım, 
yalnızca erkeklerle ilişki kurma biçiminin arkasındaki nedenleri sorgulamaya ve açıklamalar bulmaya çalışmaya değil; aynı zamanda birçok alanda "Merak ediyorum acaba neden..." gibi başlayan cümleler de kul anmaya başlamıştır ve bunların önemli gelişmeler oldukları düşünülmüştür.

Pervertler için terapi sürecinde karşlaşılan bir diğer zorluk da terapistlerini "bildiği varsayılan özne" konumuna kolayca yerleştirememeleridir. Bu zorluk, M. Hanım'ın dile getirdiği "Yııllardır terapiye geliyorum, şu hastalığımdan bir türlü kurtulamadım. Tabi bu terapistlerin beceriksizliği ile de ilgili." cümlesi ile örneklendirebilir. Terapist, terapinin kural arı "-mış gibi göründüğü” sürece, kendisinin bilen özne konumunu elde edemeyeceğinin farkında olmalıdır. Terapist, pervertin arzusunun nedeni işlevini görmek için elde ettiği bu pozisyonu ne kabul etmeli ne de reddedilmelidir. Benzer şekilde terapist, "Hayır (işlevini göreceği) varsayılan özne" konumunu da kabul etmemeli ya da reddetmemelidir. Bu pozisyonlardan herhangi birisini kabul etmek arzu yerine talep seviyesinde sıkışıp kalmak anlamına gelmektedir ki bu, ayrışmayı önleyen Öteki konumu ile yakından ilişkilidir. Sonuç olarak terapist, zevki kısıtlamak ve pervertin kendi vücudunu ve öznel iğini Ötekinden geri almasına yardımcı olmak için tavsiye vermekten ve yorum yapmaktan kaçınarak, arzu seviyesinde çalışmayı denemelidir (Swales, 2012).

\section{Tartışma}

Makalenin başında da üzerinde durulduğu gibi perversiyon, suç teşkil eden cinsel davranışlarla ilişki kurularak teşhis edilmemelidir. Bunun yerine klinisyen, genel olarak ilişkilerin pervert yapısına ve pervert öznenin bölmelemelerine odaklanmalıdır (Verhaeghe, 2008). M. Hanım'ın otorite konumundaki ötekileri değersizleştirerek onlarla ilişki kurması, yasayı koyanların çelişkiler ine dikkat çekmesi onu bu tanıya yakınlaştırmaktadır. M. Hanım'ın bölmelemelerinin keskinliği, düzenli ve düzensiz olarak tarif ettiği birbirlerine tamamen zit iki hayat düzeni arasında gel-git yaşamasıyla paral el olarak düşünülmüştür.

M. Hanım'a göre düzenli hayat, sabit bir partnerinin olduğu, yemek ve temizlik gibi ev işlerini yaptığı, evliliğe benzer bir hayat yaşadığı dönemler iken, düzensiz hayat ise tek gecelik ilişkiler yaşadığı, istediği gibi eğlenebildiği dönemlere denk gelmektedir. M. Hanım düzenli hayat sıkıcı olduğu, düzensiz hayat ise yalnızlıkla sonuçlandığı için hangisini tercih edeceğini bilmediğini söylemiş; düzenli bir hayatla eğlencenin entegre edilemeyeceğini vurgulamıştır.

Perversiyon ve histerinin paylaştığı ortak noktalardan ötürü histerik yapı içerisindeki pervert davranışlar ile pervert yapıyı birbirlerinden ayırmak oldukça zordur. Bu anlamda iki yapıyı birbirinden ayıran kriterlere dikkat edilmelidir (Verhaeghe, 2008). Perversiyonu histeriden ayıran en önemli kriterlerden birisi, histeriğin ötekinin isteğini yerine getirmekten kaçınması, yani onun arzusunu ne pahasına olursa olsun doyurmamasıdır (Nobus, 2013). M. Hanım'ın cinsel birlikteliklerindeki konumlanışı, seanslarda terapistine kurduğu, kendisini eğlence nesnesi olarak gördüğ̈̈nü yansıtan "Yeterince eğlenceli bir vaka mıyım? Benimle olan terapi sonlandığında kendinize daha eğlenceli bir vaka bulursunuz benden artık sıkılmışsınızdır gibi düşünüyorum.” şeklindeki cümleleri de M. Hanım'ın histerik yapıdansa pervert yapıya ait olduğunu düşündürmektedir. Terapiste bildiği varsayılan özne konumundan ziyade zevk alacağı varsayılan özne pozisyonu vermeye ek olarak, pervertler, terapistlerine pasif ve gözlemleyen seyirci pozisyonunu da tahsis ederler. Terapistleri seyirci pozisyonundayke $\mathrm{n}$ her zaman suçluluk hissi yaşayan nevrotiklere kıyasla da, pervertler özel ikle üçüncü bir bakışa ihtiyaç duymaktadırlar (Verhaeghe, 2008). M. Hanım'ın cep telefonundan mesajları göstererek olayları anlatmaya çalışması, erkek arkadaşının kendisini tehdit ettiği ses kaydını aniden seansta açarak terapistine dinletmesi ve günlüklerini seansa getirmesi gibi davranışları, bu ihtiyacın örnekleri olarak sayılabilirler. 


\section{Kaynaklar}

Andre, S. (2006). The structure of perversion: A Lacanian perspective. In D. Nobus, \& L. Downing (Eds.), Perversion: Psychoanalytic Perspectives/Perspectives on Psychoanalysis (ss. 109-125). London, Karnac Books.

Benvenuto, S. (2006). Perversion and charity: An ethical approach. In D. Nobus, \& L. Downing (Eds.), Perversion: Psychoanalytic Perspectives/Perspectives on Psychoanalysis (ss. 59-78). London, Karnac Books.

Bernstein, J. W. (2015). Review of Perversion: A Lacanian psychoanalytic approach to the subject. Psychoanalytic Psychology, 32(3), 553-557. doi:10.1037/a0035854

Evans, D. (1996). An Introductory Dictionary of Lacanian Psychoanalysis. New York, Routledge.

Feher-Gurewich, J. (2003). A Lacanian approach to the logic of perversion. In J. M. Rabate (Ed.), The Cambridge Companion to Lacan (ss. 191-207). New York, Cambridge University Press.

Fink, B. (1995). The Lacanian Subject: Between Language and Jouissance. Chichester, Princeton University Press.

Fink, B. (1997). A Clinical Introduction to Lacanian Psychoanalysis: Theory and Technique. London, Harvard University Press.

Julien, P. (1994). Jacques Lacan's Return to Freud: The Real, the Symbolic, and the Imaginary. London: New York University Press.

Lacan, J. (1955-1956). On a Question Prior to Any Possible Treatment of Psychosis. In B. Fink in Collaboration with H. Fink and R. Grigg (Ed. \& Çev.). Ecrits: The First Complete Edition in English, New York, Norton \& Company.

Lacan, J. (1957-1958). Book V: The Formations of the Unconscious (C. Gal agher Çev.). Unpublished typescript. Erişim http://www.lacaninireland.com/web/wp- content/uploads/2010/06/Book-05-theformations-of-the-unconscious.pdf

Lacan, J. (1962-1963). Anxiety: The Seminar of Jacques Lacan: Book X. (A. R. Price Çev.). In J. A. Mil er (Ed.). Cambridge, Polity Press.

Lacan, J. (1972-1973). On Feminine Sexuality: The Limits of Love and Knowledge, Book XX. In J. A. Miller (Ed.). Paris, Norton \& Company.

Moncayo, R. (2008). Evolving Lacanian Perspectives for Clinical Psychoanalysis: On Narcissism, Sexuation, and the Phrases of Analysis in Contemporary Culture. London, Karnac Books.

Nobus, D. (2013). Jacques Lacan and the Freudian Practice of Psychoanalysis. London, Routledge.

Penney, J. (2012). World of Perversion, The: Psychoanalysis and the Impossible Absolute of Desire. Albany, State University of New York Press.

Richards, A. K. (2003). A fresh look at perversion. Journal of the American Psychoanalytic Association, 51(4), 1199-1218.

Rusansky Drob, L. (2008). Borderline Personality Disorder: A Lacanian Perspective. Erişim https:// tr.scribd.com/doc/61467756/Borderline-Personality-Disorder-A-Lacanian-Perspective-6-30-08

Ruti, M. (2008). The fall of fantasies: A Lacanian reading of lack. Journal of the American Psychoanalytic Association, 56(2), 483-508.

Swales, S. (2010). Psychosis or Neurosis? Lacanian Diagnosis and Its Relevance for Group Psychotherapists. Group, 34 (2), 129-143.

Swales, S. (2012). Perversion: A Lacanian Psychoanalytic Approach to the Subject. New York, Routledge.

Taheri, A. (2016). Perverse Mothers or Mad Wives?: A Lacanian Commentary on Nahaleh Moshtagh's "The Repression of the Bad Oedipal Mother in Psychoanalysis”. Erişim http://psychoanalyticdiscourse. com/index.php/psad/article\%20/view/34/68 
Verhaeghe, P. (2001). Perverse traits. The Letter (Dublin), 22, 59-75. Retrieved from http:// whatispsychoanalysis.ie/wp-content/uploads/2015/05/THE- LETTER-22-Summer-2001-pages-5974.-P.-Verhaeghe-Perversion-I PerverseTraits.pdf\&gws_rd=cr\&ei=KD6UWJBTiYBpjO iHsAI

Verhaeghe, P. (2001). Perversion II: The perverse structure. The Letter (Dublin), 23, 77-95. Retrieved from http://www.psychoanalysis.ugent.be/pages/nl/artikels/artikels\%2520Paul\%2520Verhaeghe/ Perversion\%2520II.pdf $+\& \mathrm{~cd}=1 \& \mathrm{hl}=\mathrm{tr} \& \mathrm{ct}=\mathrm{clnk} \& \mathrm{gl}=\mathrm{tr}$

Verhaeghe, P. (2008). On Being Normal and Other Disorders: A Manual for Clinical Psychodiagnostic. London, Karnac Books. 


\section{Summary \\ The Concept of Perverse Structure from Lacanian Perspective and Therapeutic Recommendations}

In the literature, perversion is mostly understood from the perspective of performing "transgressive acts" but Lacan described it as a third clinical structure in addition to neurosis and psychosis. Understanding the features of those three clinical structures and discussing how they are different from each other are important since the structures provide a treatment model beyond merely offering descriptive diagnoses based on particular symptoms. In perversion, subject cannot say "No" to being the object of mOther's jouissance since the second paternal function, the Name of Father, that paves the way to him or her for separation from mOther, cannot be effective. Maternal discourse diminishing the paternal function into appearances, inconsistent attitude of parents, that is, putting limits only when they become angry with the child, and being exposed to incest and sexual abuse are some of the reasons behind the failure of second paternal function. As a result of that failure, the perception of lack perceived in mother is disavowed since it is traumatic for a child, unless the lack is symbolized by that function. That is, disavowal mechanism is a tool of perverts to cope with weakness of the paternal function that is required to limit "jouissance". To illustrate the characteristics of perverse structure, a case will be elaborated. Moreover, the therapeutic recommendations based on Lacanian approach for perverse structure will be provided and some examples from the therapy sessions conducted by the case will be given.

Keywords: perversion, jouissance, paternal function 